\title{
HUBUNGAN TINGKAT PENGETAHUAN TERHADAP KEBERHASILAN PENGOBATAN TUBERKULOSIS DI PUSKESMAS KECAMATAN JOHAR BARU TAHUN 2016
}

\author{
Nurul Amalia Utami ${ }^{1}$, Insan Sosiawan A Tunru' ${ }^{1}$, Yusnita ${ }^{1}$ \\ ${ }^{1}$ Fakultas Kedokteran, Universitas Yarsi Jakarta Pusat, Indonesia \\ Email: nurulamaliautm@gmail.com
}

\begin{abstract}
ABSTRAK
Tuberkulosis (TB) merupakan penyakit menular yang disebabkan kelompok bakteri Mycobacterium, yaitu Mycobacterium tuberculosis. Terdapat enam negara dengan jumlah insiden TB terbanyak di dunia, termasuk di dalamnya Indonesia dengan prevalensi 1.020 per 100.000 penduduk yang berada diposisi kedua setelah India. Berdasarkan hasil monitoring dan evaluasi Tuberculosis External Monitoring Mission Teamtahun 2008, keberhasilan pengobatan masih rendah. Banyak faktor yang mempengaruhi keberhasilan pengobatan tuberkulosis salah satunya tingkat pengetahuan. Penelitian inibertujuan untuk melihat dan membuktikan ada tidaknya hubungan tingkat pengetahuan terhadap keberhasilan pengobatan pada pasien tuberkulosis dan dilakukan secara cross sectional. Hasil penelitian menunjukkan terdapat jumlah responden yang berhasil dalam pengobatan sebanyak 45 orang $(80,4 \%)$ dan untuk tingkat pengetahuan sebagian besar responden memiliki tingkat pengetahuan baik yaitu, sebanyak 22 orang (39,3\%)dari 56 sampel. Dari hasil uji statistikmenggunakan uji ChiSquare didapatkan nilai $\mathrm{P}>0,05$ yaitu 0,069 .
\end{abstract}

Kata Kunci: Tuberkulosis, pengetahuan, dan keberhasilanpengobatan

\begin{abstract}
Tuberculosis (TB) is a contagious disease caused by the group of Mycobacterium bacteria, Mycobacterium tuberculosis. There are six countries with the highest number of TB incidents in the world, including Indonesia with a prevalence of 1,020 per 100,000 inhabitants located second after India. Based on the results of monitoring and evaluation of Tuberculosis External Monitoring Mission Team in 2008, the success of treatment is still low. Many factors that influence the success of tuberculosis treatment one of them is the level of knowledge. This study aims to see and prove whether there is a relationship of knowledge level to the success of treatment in patients with tuberculosis and done cross-sectional. The result of the research shows that there are 45 respondents $(80,4 \%)$ and the knowledge level of the respondent has good knowledge, 22 people (39,3\%) from 56 samples. From the results of statistical tests using Chi-Square test obtained $P$ value $>0.05$ is 0.069 .
\end{abstract}

Keywords: Tuberculosis, knowledge, and treatment success 


\section{Pendahuluan}

$\begin{array}{rrr}\text { Tuberkulosis } & \text { (TB) merupakan } \\ \text { penyakit menular yang disebabkan }\end{array}$ kelompok bakteri Mycobacterium, yaitu Mycobacterium tuberculosis. TB menular secara droplet infection atau percikrenik, kumannya menyebar melalui udara pada saatbersin, batuk, ataupun berbicara ${ }^{1}$.

Pada tahun 2010 terdapat 8,8 jutakasusbaru TB parudengan 3,9 jutaadalahkasus BTA (Basil TahanAsam) positif. Menurut data World Health Organization (WHO) jumlah terbesar kasus TB paru terjadi di Asia Tenggara, yaitu $33 \%$ dari seluruh kasus TB paru di dunia. Angka kematian akibat TB paruadalah 8000 setiaphari dan 2-3 juta setiap tahun. Jumlah terbesar kematian akibat TB paruter dapat di Asia Tenggara yaitu 625.000 orang atau angka mortalitas sebesar 39 orang per 100.000 penduduk $^{2}$.

Terdapat enam negara dengan jumlah insiden TB terbanyak di dunia, termasuk didalamnya Indonesia dengan prevalensi 1.020 per 100.000 penduduk yang berada diposisi kedua setelah India ${ }^{3}$. Tiga provinsi dengan insidensi kejadian TB parutertinggi di Indonesia adalah Jawabarat $(0,7 \%)$, Papua $(0,6 \%)$, dan DKI Jakarta $(0,6 \%)$ didapat dari hasil Riset Kesehatan Dasar $2013^{2}$.

Menurut laporan Dinas Kesehatan Provinsi DKI Jakarta tahun 2016, jumlah penderita TB Paru Klinis dengan suspek ditemukan di Provinsi DKI Jakarta pada tahun 2015 sebanyak 26,499 penderita ${ }^{4}$.

Di Indonesia, upaya pengendalian TB sudah berlangsung sejak sebelum kemerdekaan. Hingga pada tahun 1995 sampai sekarang pengendalian TB dilakukan mengunakan strategi DOTS (Directly Observed Treatment, Shortcourse Chemotheraphy) ${ }^{1}$.

Upaya pemerintah sudah banyak dilakukan dalam menanggulangi kasus TB di Indonesia. Namun, berdasarkan hasil monitoring dan evaluasi Tim TB External Monitoring Mission tahun 2008, keberhasilan pengobatan masih rendah dengan angka putus berobat yang cukup tinggi ${ }^{5}$. Banyak faktor yang berpengaruh terhadap keberhasilan pengobatan TB diantaranya, kepatuhan, pengetahuan, persepsi, status sosialekonomi, lama pengonbatansertaperanpetugas kesehatan ${ }^{6}$.

Penyakit ini dapat berakibat pada kematian, umumnya karena kegagalan pengobatan akibat putu sobat yang dipengaruhi oleh kurangnya pengetahuan mengenai tuberkulosis, fakto rekonomi rendah, pengobatan yang tidak teratur, adanya penyakit penyerta dan kebiasaan merokok $^{2}$.

Berdasarkan penelitian yang dilakukan Pasek dan Satyawantahun $2013^{6}$, tingkat pengetahuan yang tinggi akan mempengaruhi kepatuhan berobat pasien TB sehingga dapat meningkatkan 
keberhasilan pengobatan. Hal ini tidak sejalan dengan penelitian yang dilakukan Zanani (2009) ${ }^{7}$ yang menyatakan tingkat pengetahuan yang lebih tinggi tidak selalu mempengaruhi sikap dan tindakan pasien TB selama menjalani pengobatan sehingga menyebabkan keberhasilan pengobatan masih rendah.

Pada penelitian Munirok dkk $(2013)^{8}$ juga menyatakan, bahwa ada beberapa faktor yang sangat berperan dalam keberhasilan pengobatan TB selain pengetahuan pasien yaitu, dukungan keluarga dan masyarakat disekitar pasien tuberkulosis.

Berdasarkan paparan masalah tersebut, peneliti ingin melakukan penelitian untuk melihat dan membuktikan ada tidaknya hubungan tingkat pengetahuan terhadap keberhasilan pengobatan pada pasien tuberkulosis di Puskesmas Kecamatan Johar Baru Jakarta Pusat tahun 2016.

\section{Metode Penelitian}

Penelitian ini dilakukan secara cross sectional. Populasi penelitian adalah pasien TB yang berobat ke Puskesmas Kecamatan Johar Baru Jakarta Pusat tahun 2016 sebanyak 125 orang. Sampel dipilih dengan menggunakan metode Simple Random Sampling dan didapatkan jumlah sampel56 orang. Responden pada penelitian ini merupakan pasien $\mathrm{TB}$ di
Puskesmas Kecamatan Johar Baru Jakarta Pusat tahun 2016 yang memenuhi criteria inklusi dan criteria eksklusi penelitian. Kriteria inklusi pada penelitian ini adalah pasien berusia> 15 tahun yang telah menyelesaikan pengobatan selama 6 bulan, bersedia sebagai sampel penelitian ini serta alamat responden yang dapat dijangkau oleh peneliti. Untuk criteria eksklusi yaitu pasien TB yang tidak bersedia mengikuti penelitian dan tidak sesuai dengan criteria inklusi penelitian.

Instrumen pengumpulan data menggunakan informed consent dan kuisioner penelitian serta buku TB 03 di Puskesmas Kecamtan Johar Baru Jakarta Pusat tahun 2016. Pengambilan data dilakukan dengan wawancara yang dipandu kuisioner. Analisis bivariat dalam penelitian ini menggunakan uji ChiSquare dan diolah menggunakan program SPSS 23 for windows.

\section{Hasil}

Pada tabel 4.1 terlihat bahwa mayoritas responden berjenis kelamin lakilakiyaitu 30 orang $(53,6 \%)$. Berdasarkan usia sebagian besar responden berusia $<40$ tahunyaitu 29 orang $(51,8 \%)$. Pendidikan responden sebagian besar SD dan SMA dengan banyak masing-masing samayaitu, 18 orang $(32,1 \%)$.Pada tabel 4.2 terlihat bahwa jumlah responden yang berhasil 
Tabel 4.1 Karakteristik responden

\begin{tabular}{ccc}
\hline Variabel & Jumlah & Presentase (\%) \\
\hline Jenis kelamin & 30 & \\
Laki - laki & 26 & 53,6 \\
Perempuan & $\mathbf{5 6}$ & 46,4 \\
Subtotal & & $\mathbf{1 0 0}$ \\
Umur & 29 & \\
<40 tahun & 27 & 51,8 \\
$>40$ tahun & $\mathbf{5 6}$ & 48,2 \\
Subtotal & & $\mathbf{1 0 0}$ \\
Pendidikan terakhir & 3 & 5,4 \\
Tidak tamat SD & 18 & 32,1 \\
SD & 13 & 23,2 \\
SMP & 18 & 32,1 \\
SMA & 4 & 7,2 \\
Akademi/ Sarjana & $\mathbf{5 6}$ & $\mathbf{1 0 0}$ \\
Subtotal & &
\end{tabular}

Tabel 4.2 Hubungan Tingkat Pengetahuan Terhadap Keberhasilan Pengobatan TB Di Puskesmas Kecamatan Johar Baru Jakarta Pusat Tahun 2016

\begin{tabular}{lllll}
\hline \multirow{2}{*}{ Tingkat Pengetahuan } & \multicolumn{2}{l}{ Keberhasilan Pengobatan } \\
Berhasil & Tidak berhasil & Total \\
\hline Baik & Jumlah & 18 & 4 & 22 \\
& Persentase & $81,8 \%$ & $18,2 \%$ & $100 \%$ \\
Cukup & Jumlah & 12 & 3 & 15 \\
& Persentase & $80.0 \%$ & $20.0 \%$ & $100 \%$ \\
\multirow{3}{*}{ Kurang } & Jumlah & 15 & 4 & 19 \\
& Persentase & $79.0 \%$ & $21.0 \%$ & $100 \%$ \\
\hline
\end{tabular}


Dalam pengobatannya sebanyak 45 orang $(80,4 \%)$.

Gambaran tingkat pengetahuan pada tabel 4.3 terdapat sebagian responden memiliki tingkat pengetahuan baik sebanyak 22 orang (39,3\%). Dari hasil uji statistic menggunakan uji Chi-Square didapatkan nilai $\mathrm{P}>0,05$ yaitu 0,069 . Hal ini memperlihatkan bahwa tidak ada hubungan tingkat pengetahuan terhadap keberhasilan pengobatan pada pasientuberkulosis di Puskesmas Kecamatan Johar Baru Jakarta Pusat tahun 2016.

\section{Pembahasan}

Pada penelitian ini tingkat pengetahuan pasien TB diukur dari penilaian kuesioner dan dibagi menjadi tiga kategori yaitu, pengetahuan baik (skornya 76-100), cukup (skornya 56-75), dan pengetahuan kurang (skornya 0-55). Untuk keberhasilan pengobatan dilihat dari keterangan pada kartu TB03 yang ada di Puskesmas Kecamatan JoharBaru Jakarta Pusat periodetahun 2016.

Pasien TB yang dikategorikan telah berhasil dalam penelitian ini adalah pasienTB dengan pemeriksaan BTA (+) yang telah menjalani masa pengobatan selama 6 bulan atau telah dinyatakan ada perubahan hasil pemeriksaan BTA menjadi $(-)$.
Hasil uji statistik pada penelitianini menggunakan uji Chi-Square didapatkan nilai $\mathrm{p}=0,069$ menyatakan bahwa $\mathrm{HO}$ diterima, yaitu tidak adanya hubungan antar atingkat pengetahuan terhadap keberhasilan pengobatan pada pasien TB di Puskesmas Kecamatan Johar Baru Jakarta Pusat tahun 2016. Hasil pada penelitian ini sama seperti penelitian yang dilakukan oleh Yuni (2016) ${ }^{9}$ menyatakan, bahwa pasien TB dengan tingkat pengetahuan tinggi, 50,8\% gagal dalam menjalani fase pengobatan. Hasil analisis uji Chi-Square yang dilakukanRuditya $(2015){ }^{10}$ dengan $\quad p \quad$ sebesar 0,712 menunjukan tidak adanya hubungan antara tingkat pengetahuan penderita TB dengan kepatuhan memeriks akan dahak selama pengobatan, dimana pemeriksaan dahak secara rutin akan berdampak pada hasil pengobatan yang dilakukan.

Hal ini dapat disebabkan karena lamanya jangka waktu yang diperlukan dalam menjalani pengobatan TB, sehingga tingginya tingka tpengetahuan yang dimiliki pasien TB tidaklah cukup untuk menunjang keberhasilan pengobatan yang dijalaninya. Ada faktor-faktor penting lainnya seperti dukungan serta peran keluarga dan masyarakat disekitar pasien TB dalam membantu menjaga kepatuhan pasien TB untuk selalu meminum obat dengan teratur setiap harinya selama masa pengobatan $^{11}$. 
Keluarga sangat mempengaruhi keberhasilan pengobatan pada pasien TB karena kebanyakan PMO yang baik adalah keluarga pasiensen diri sehingga memilik kewenangan khusus dalam mengingatkan dan memastikan pasien TB meminum obatnya dengan teratur dan rutin serta selalu melakukan pemeriksaan dahak ulang sesuai jadwal yang dianjurkan oleh dokter. Selain itu, keluarga juga berperan dalam memberikan dukungan moril dan instrumental berupa dana dan waktu selama mendampingi pasien TB menjalani pengobatan $^{8}$.

Pada penelitian ini terdapat beberapa keterbatasan seperti, keterbatasan dana dan waktu peneliti yang menyebabkan beberapa sampel terpilih berdasarkan hasil simple random sampling tidak semua berada ditempat saat peneliti melakukan kunjungan penelitian. Sehingga, dibantu oleh kader yang memiliki pengalaman dengan penelitian serupa mengganti dengan pasien TB yang berobatke Puskesmas Johar Baru Tahun 2016 yang biasa bersedia mengikuti penelitian yang telah selesai masa pengobatan pada tahun 2016 .

Selain itu, dalam pengisian kuesioner tingkat pengetahuan yang berkaitan tentang lamanya pengobatan dan waktu minum obat, beberapa dari responden hanya memperkirakan dikarenakan sudah lamanya responde nmenyelesaikan masa pengobatan yang dijalani.

\section{Kesimpulan}

Berdasarkan hasil penelitian ini, tidak ada hubungan tingkat pengetahuan terhadap keberhasilan pengobatan pada pasien tuberkulosis di Puskesmas Kecamatan Johar Baru Jakarta Pusat tahun 2016.

\section{Ucapan Terimakasih}

Saya ucapkan terima kasih kepada guru saya dr.Insan Sosiawan dan dr.Yusnita yang telah membimbing, member dukungan serta saran selama penelitian berlangsung. Terima kasih kepada para petugas kesehatan di Puskesmas Kecamatan Johar Baru Jakarta Pusat yang telah banyak membantu selama penelitian.

\section{Daftar Pustaka}

1. Kemenkes RI. 2014. Pedoman Nasional Pengendalian Tuberkulosis. Direktorat Jendral Pengendalian Penyakit dan Penyehatan Lingkungan. Available form:

http://www.tbindonesia.or.id/opend ir/Buku/bpn_p-tb_2014.pdf [citied September 17, 2016].

2. Depkes RI 2013. Riset Kesehatan Dasar. Available form: http://www.depkes.go.id/resources/ 
download/general/Hasil\%20Riskes das\%202013.pdf [citied October 10, 2016].

3. World Health Organization (WHO). 2015. Global Report Tuberculosis. Available form : http://apps.who.int/iris/bitstream/1 0665/191102/1/9789241565059_en g.pdf [cited October 23, 2016].

4. Depkes RI 2015. Profil Kesehatan Provinsi DKI Jakarta Tahun 2012. Available form: http://www.depkes.go.id/resources/ download/pusdatin/profilkesehatan-indonesia/profilkesehatan-indonesia-2012.pdf [citied September 18, 2016

5. Depkes RI. 2009. Pedoman Nasional Penanggulangan TBC. Ed.2: Cetakan II. Jakarta: Depkes RI.

6. Pasek, M.S dan Satyawan, I.M. HubunganPersepsi dan Tingkat Pengetahuan Tuberkulosis dengan Kepatuhan Pengobatan di Kecamatan Buleleng. Jurnal Pendidikan Indonesia 2013;Vol.2;No.1;pp. 145-152. April.

7. Zanani, Mayasari. Hubungan Dukungan Keluarga dengan Kepatuhan Berobat Pasien TB Paru di Puskesmas Torjun
Kabupaten Sampang. Surabaya: Universitas Airlangga.; 2009.

8. Muniroh, Nuha. Faktor-faktor yang berhubungan dengan kesembuhan penyakit TBC Paru di wilayah kerja Puskesmas Mangkang Semarang Barat. Jurnal keperawatan komunitas 2013: Vol.1;No.1;pp.33-42. Mei.

9. Yuni, I.D.A.M.A. Hubungan fase pengobatan $T B$ dan Pengetahuan tentang MDR TB dengan kepatuhan pengobatan pasien TB (Studikasus di Puskesmas Perak Timur). Jurnal berkala epidemiologi 2016: Vol.4;No.3;pp.301-312.

September.

10. Ruditya, D.N. Hubungan antara karakteristik penderita TB dengan kepatuhan memeriksakan dahak selama pengobatan. Jurnal berkala epidemiologi 2015: Vol.3; No.2;pp.122-133. Mei.

11. Zuliana, Imelda. Pengaruh Karakteristik Individu FaktorPelayanan Kesehatan dan Faktor Peran Pengawas Menelan Obatter hadap Tingkat Kepatuhan Penderita TB Parudalam Pengobatan di Puskesmas Pekan Labuhan Kota Medan. 